\title{
Longwy
}

Rue Margaine

\section{Murielle Georges-Leroy}

\section{(2) OpenEdition}

1 Journals

Édition électronique

URL : http://journals.openedition.org/adlfi/9098

ISSN : 2114-0502

Éditeur

Ministère de la culture

Référence électronique

Murielle Georges-Leroy, "Longwy », ADLFI. Archéologie de la France - Informations [En ligne], Lorraine, mis en ligne le 01 mars 2001, consulté le 02 mai 2019. URL : http://journals.openedition.org/ adlfi/9098

Ce document a été généré automatiquement le 2 mai 2019.

(c) Ministère de la Culture et de la Communication, CNRS 


\section{Longwy}

Rue Margaine

\section{Murielle Georges-Leroy}

Identifiant de l'opération archéologique : F1354200100027

Date de l'opération : 2001 (EV)

1 Deux sondages d'évaluation archéologique ont été réalisés préalablement à la construction d'un ensemble de logements, sur une surface d'environ $700 \mathrm{~m}^{2}$, sur des terrains localisés à l'intérieur des fortifications de la place forte de Longwy-Haut, construite au XVII ${ }^{\mathrm{e}}$ s. par Vauban. Sur le plan de la place forte en 1762, l'îlot concerné est bâti. Au moment de la réalisation des sondages, la parcelle était entièrement occupée par un jardin. Les sondages ont mis au jour les substructions d'anciens bâtiments sur cave, datant probablement des XVII ${ }^{e}$ s. ou XVIII ${ }^{e}$ s. Les substructions ont été remblayées par des gravats datant d'une vingtaine d'années. L'épaisseur de ces gravats varie de 0,60 $\mathrm{m}$ dans les zones non construites à plus de 2,30 $\mathrm{m}$ (fond non atteint) au niveau des caves.

\section{INDEX}

Index géographique : Lorraine, Meurthe-et-Moselle (54), Longwy

Thèmes : bâtiment militaire, cave, fortification, habitat, jardin

operation Fouille d'évaluation (EV)

Index chronologique : ép. contemporaine, Temps Modernes, XVIIe siècle apr. J.-C., XVIIIe siècle apr. J.-C. 
AUTEURS

MURIELLE GEORGES-LEROY

SDA 